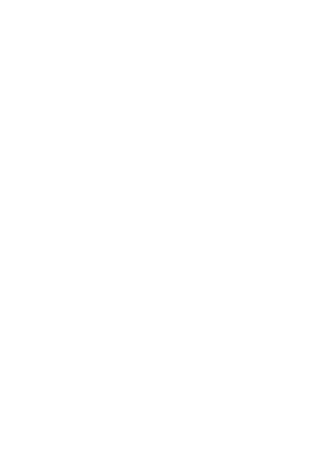

Journal of Geology,

\title{
Geospatial Technology for Landslide Susceptibility Mapping along the Vathalmalai Ghat road section, South India
}

\author{
G. Kavitha ${ }^{1}$, S. Anbazhagan ${ }^{1}$, S. Mani ${ }^{2}$ \\ ${ }^{1}$ Centre for Geoinformatics and Planetary Studies, Periyar University, Salem, India, anbu02@gmail.com \\ ${ }^{2}$ School of Civil Engineering, SASTRA Deemed University, Thanjavur, India
}

Received: 04.02.2021

Received in revised form: 14.04.2021

Accepted: 09.08.2021

Abstract. Landslides are among the most prevalent and harmful hazards. Assessment of landslide susceptibility zonation is an important task in reducing the losses of life and properties. The present study aims to demarcate the landslide prone areas along the Vathalmalai Ghat road section (VGR) using remote sensing and GIS techniques. In the first step, the landslide causative factors such as geology, geomorphology, slope, slope aspect, land use / land cover, drainage density, lineament density, road buffer and relative relief were assessed. All the factors were assigned to rank and weight based on the slope stability of the landslide susceptibility zones. Then the thematic maps were integrated using ArcGIS tool and landslide susceptibility zonation was obtained and classified into five categories ; very low, low, moderate, high and very high. The landslide susceptibility map is validated with R-index and landslide inventory data collected from the field using GPS measurement. The distribution of susceptibility zones is ; $16.5 \%$ located in very low, $28.70 \%$ in low, $24.70 \%$ in moderate, $19.90 \%$ in high and $10.20 \%$ in very high zones. The R-index indicated that about $64 \%$ landslide occurences correlated with high to very high landslide susceptiblity zones. The model validation indicated that the method adopted in this study is suitable for landslide disaster mapping and planning.

Keywords: Landslides, Remote sensing and GIS, Causative factors, Susceptibility.

\section{Геопросторова технологія картографування зсувонебезпечної ділянки уздовж дороги у гірському пасмі Ваталмалай, Південна Індія}

\author{
Г. Кавіта ${ }^{1}$, С. Анбажаган, ${ }^{1}$ C. Мані ${ }^{2}$
}

${ }^{1}$ Центр геоінформатики та планетарних досліджень, Університет Періяр, Салем, Індія, anbu02@gmail.com ${ }^{2}$ Школа будівництва, Академія мистеитв, науки, технологій та досліджень Шанмуги (SASTRA), Tханджавур, Індія

\begin{abstract}
Анотація. Зсув грунту є однією з поширених та шкідливих небезпек у порівнянні з іншими катастрофами. Оцінка зональності сприйнятливості до зсувів $є$ важливим завданням щодо зменшення людських втрат та майна. Дане дослідження має на меті розмежування зсувних територій уздовж ділянки дороги Ватхалмайлай Гат (VGR) з використанням методів дистанційного зондування та ГІС. На першому етапі були встановлені чинники, що спричиняють зсув, такі як геологія, геоморфологія, схил, схиловий аспект, використання землі / покрив землі, щільність дренажу, щільність перекриття, буфер дороги та відносний рельєф. Усі фактори були оцінені за рангом та вагомістю виходячи зі стійкості схилів до зсуву. Потім тематичні карти були інтегровані за допомогою інструменту ArcGIS, і було отримано зонування сприйнятливості до зсувів та класифіковано у п'ять категорій, таких як дуже низькі, низькі, помірні, високі та дуже високі. Карта сприйнятливості до зсувів валідується за допомогою R-індексу та даних інвентаризації зсувів, зібраних у польових умовах за допомогою вимірювання GPS. Розподіл зон сприйнятливості становить $16,5 \%$ у дуже низьких, 28,70\% у низьких, 24,70\% у помірних, 19,90\% у високих i $10,20 \%$ у дуже високих зонах. R-індекс вказує, що близько 64\% випадків зсувів корелюються із високими та дуже високими зонами сприйнятливості до зсувів. Валідація моделі показала, що метод, прийнятий у цьому дослідженні, підходить для картографування та планування зсувів.
\end{abstract}

Ключові слова: зсуви, дистанційне зондування та ГІС, причинні фактори, сприйнятливість.

\section{Introduction}

Landslides affect a significant impact on people's life and their property. They are among the costliest and most damaging geological hazards in many parts of the world. In landslide mass movement terrain, the loam or debris material along with the inclined sloping terrain causes major natural disasters, loss of lives, damage to infrastructure and properties throughout 
the world (Varnes 1978; Aleotti and Chowdhury 1999; Dai et.al., 2002; Wang et.al 2015). In general, landslide susceptibility mapping is defined as qualitative methods which are direct hazard mapping techniques or quantitative methods which are indirect mapping techniques (Jaupaj et al 2014). Landslide occurrences are mainly controlled by various geo environmental parameters of the terrain (Anbazhagan and Ramesh 2014). In most mountainous terrain, geomorphology plays a significant role in the occurrence of landslides, so necessary importance has to be given to appraisal of geomorphology in landslide studies. (Sajinkumar and Anbazhagan,2014). At some locations, the development of fractures and land subsidence provide early warning for slope failure (Anbazhagan et al 2008) and one has to seriously look for such evidences in ghat road sections. Geospatial technology is widely utilized for landslide inventory, hazard zonation mapping through integration of causative factors, risk assessment and mitigation (Sajinkumar et al 2013; Anbazhagan et al 2017; Ramesh et al 2017; Amit et.al 2019). GIS based multi criteria analysis has been effectively implemented to create landslide susceptibility zonation mapping on CNG-37 ghat road section (Saranaathan and Mani 2016). In this study, several factors such as geology, geomorphology, aspect, land use /land cover, drainage density, lineament density, road buffer, slope angle, relative relief and rainfall density were considered. Similarly, GIS technique has been adopted for multi criteria analysis of Bodimettu ghat section (Kannan et.al 2011). Many researchers have used different methods for landslide susceptibility zonation mapping (Sarkar and Kanungo 2004); Arnous 2011; Ahmed 2015; Mahdadi et.al 2018, Amit et.al 2019; Sharma and Mehta 2012; Maheep et.al 2018; Lee et.al 2004; Meng et.al 2011; Hong et.al 2007). Overall, the GIS based multi criteria decision analysis is simple and it provides convincing results for zones of landslide hazards. Vathalmalai was comparatively little known prior to 2012 when the hilly terrain attracted attention through being announced by the Government of Tamil Nadu as a tourist spot in Dharmapuri district. In consequence of new road construction along the Ghat section leading to slope failure at several locations, Kavitha et al 2020a have carried out preliminary studies on landslide inventory and volume estimation. Several causative parameters in the hilly terrain were integrated for preparation of a landslide hazard zonation map though the Landslide Hazard Evaluation Factor method (Kavitha et al 2020b). The main objective of the present study is to assess the landslide susceptibility zones along the Vathalmalai Ghat road using multi-criteria analysis.

\section{Study area}

The study area Vathalmalai is a fast-growing tourist spot located in Dharmapuri district, Tamil Nadu state, India. The geographical area is located between $12^{\circ} 02^{\prime} 18^{\prime \prime}-12^{\circ} 04 ' 15^{\prime \prime} \mathrm{N}$ latitudes and longitudes of $78^{\circ} 10^{\prime} 30^{\prime \prime}-78^{\circ} 13^{\prime} 15^{\prime \prime}$ E. Vathalmalai Periyur is a small village located at $1140 \mathrm{~m}$ above mean sea level (msl) and $25 \mathrm{~km}$ away from Dharmapuri town. Until 2010 there was no proper road connectivity and transport facility available for the people who lived in this hilly terrain. They couldn't cultivate any cash crops. The majority of the people living in the Vathalmalai Hills belong to the tribal community. They have to walk at least $12 \mathrm{~km}$ to access transport facilities in the foot hills. They are also forced to sell their cultivated products for their livelihood at a lowest cost. In the year 2012, the Government of Tamil Nadu announced Vathalmalai as a tourist spot and proposed several development plans. At present, a ghat road connects the Dhinnahalli village in the foothills to Periyur Potlangadu located on the hilltop in Vathalmalai (Fig.1). The ghat road was constructed and maintained by the District Forest Department. Geologically, the road is covered by weathered gneiss and charnockite formation. The elevation of hill ranges between $500 \mathrm{~m}$ and $1180 \mathrm{~m}$ above msl. A series of landslides occurred during November 2015 and May 2016, which were triggered by heavy rainfall. The transport was totally cut off for several days and people located on the hill suffered numerous difficulties.

\section{Methodology}

The Weighted Linear Combination (WLC) method applying weight values of each thematic factor is applied for landslide susceptibility mapping. It consists of a process of thematic layer, database generation, assignment of weightage to each factor and validation of the landslide model. In this study, nine landslide causative factors were considered; geology, geomorphology, land use/ land cover, slope, slope aspect, drainage density, lineament density, road buffer and relative relief. A Survey of India (SOI) toposheet was used for preparation of the drainage map and contour map with $20 \mathrm{~m}$ intervals on the scale 1:50,000. Slope and slope aspect were derived from the SRTM DEM data and spatial analysis tools using ArcGIS 10.4.1 software. The Geology map was prepared from the Geology and Mineral map of Tamil Nadu and Pondicherry (1995). The geomorphology, land use and land cover, lineament and road maps were derived from IRS P6 LISS -III satellite imagery. 


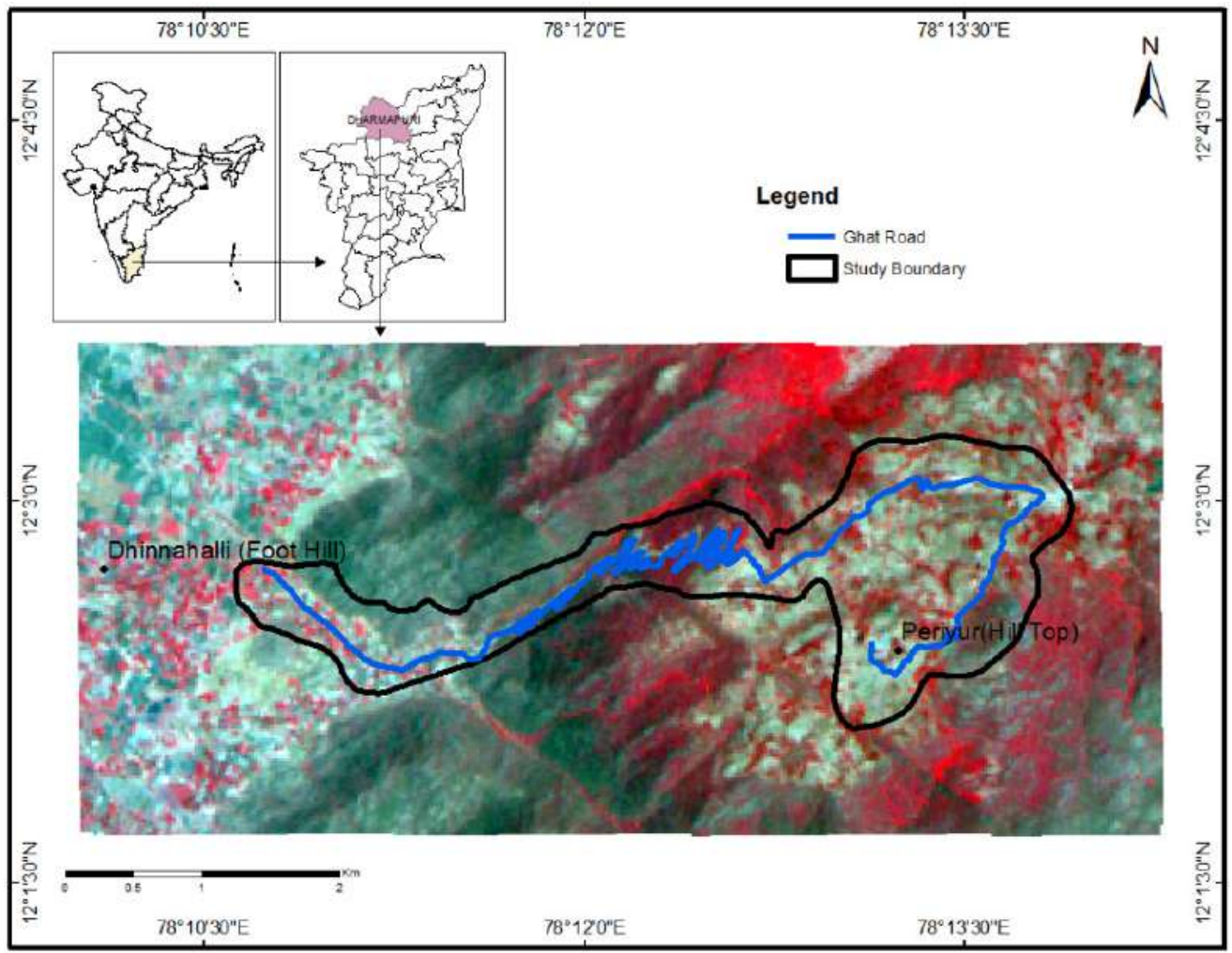

Fig.1. Location map of Vathalmalai Hills in the state of Tamil Nadu, India

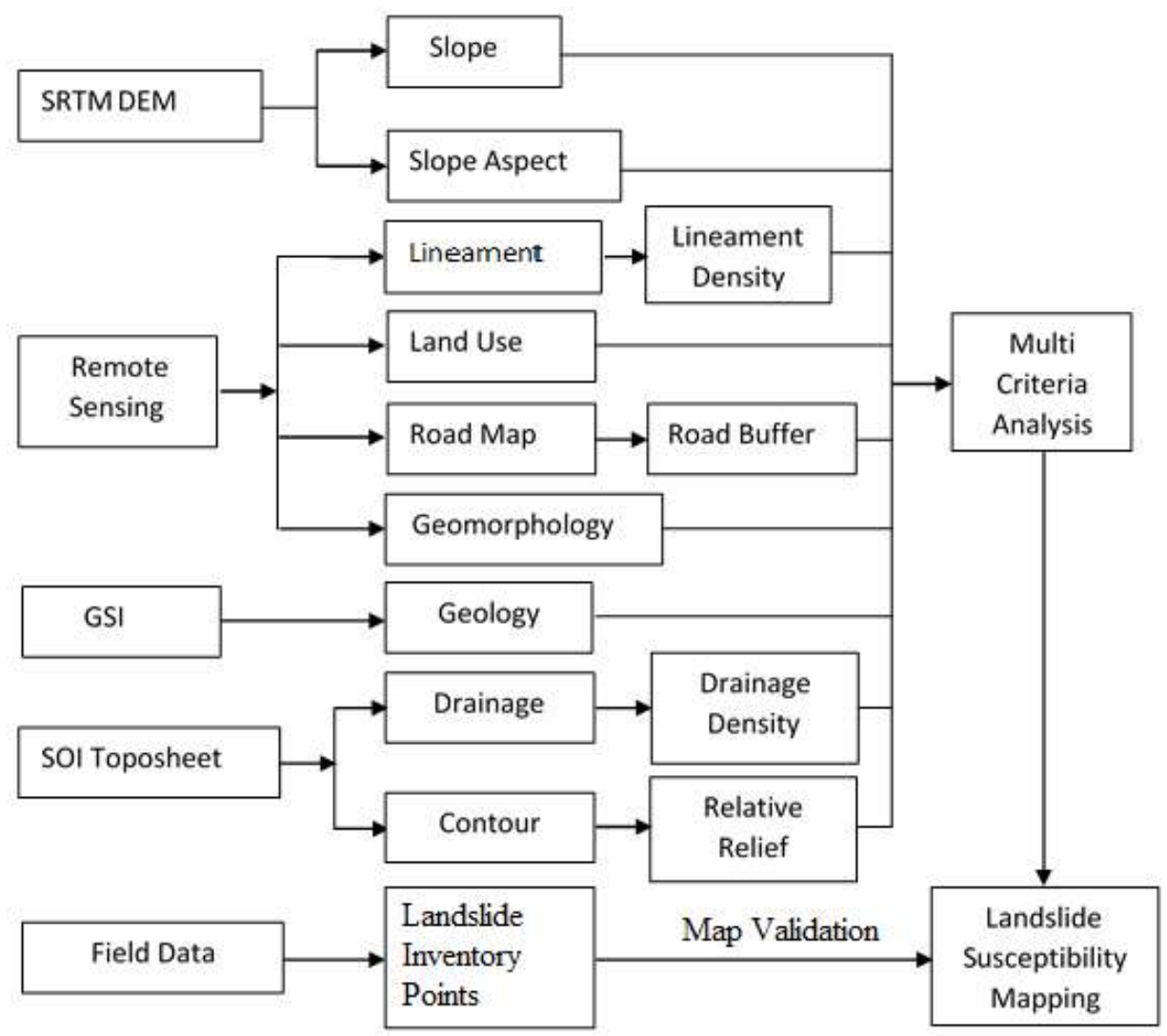

Fig. 2. Flow Chart shows the Methodology adopted in the study 


\section{Landslide Causative Factors}

\section{Geology}

Geology is one of the main factors have a direct influence on the occurrence of landslides (Wang et al 2009). In the study area, there is not much variation in lithology. The major rock types in the study area are charnockites and basic alkaline dykes (Fig.3). The rock prone to weathering has the greatest influence on occurrence of landslides Accordingly, ranking and weights were assigned.

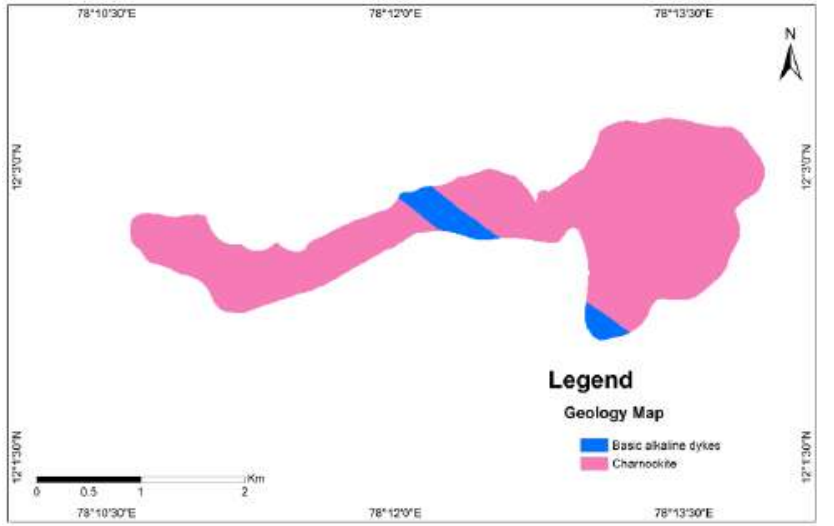

Fig. 3. Geology of the study area mostly covered by Charnockite rocks

\section{Geomorphology}

Geomorphology is one of the important parameters active in occurrence of landslides. In the present study, IRS P6 LISS III satellite imagery was interpreted to delineate different geomorphological features in the study area. The interpreted features were verified during field investigation. The structural hill system, pediment and fracture valley are the important geomorphological features in the study area (Fig.4).

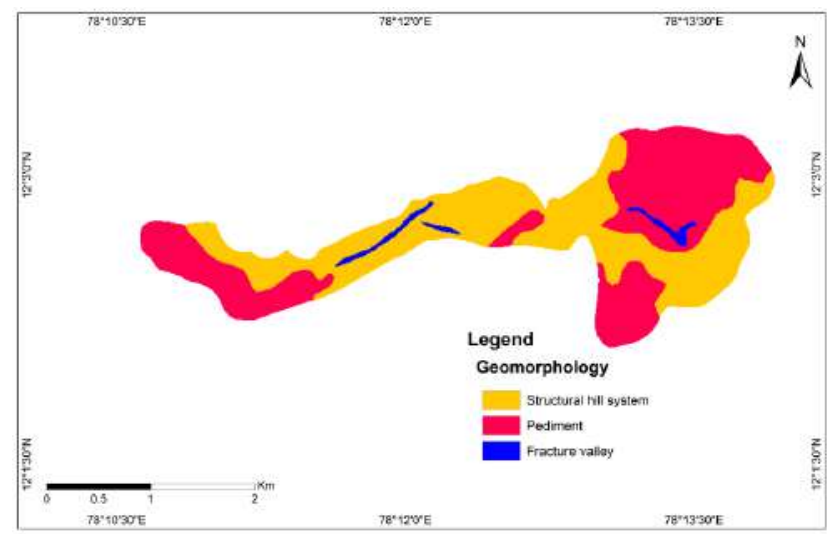

Fig. 4. Geomorphological features in the study area

\section{Land use and land cover}

Land use / land cover is one of the most sensitive parameters in the study and it is easily affected by changes resulting from the environment and human activities (Begueria, 2006). The type of vegetation is affected by the soil hydrology during increased rainfall interception, infiltration and evapotranspiration. The land use / land cover in the Vathalmalai Hill region was prepared from IRS P6 LISS III satellite image and toposheet. The major types of land use and land cover in the study area are fairly dense scrub, flat land, moderately vegetated areas, plantations and settlements. Out of these, dense scrub and vegetation occupy the major portion of the hills (Fig.5). Though different land cover occupied the entire hill system, the forest cover is degrading at a faster rate due to frequent landslide occurrences.

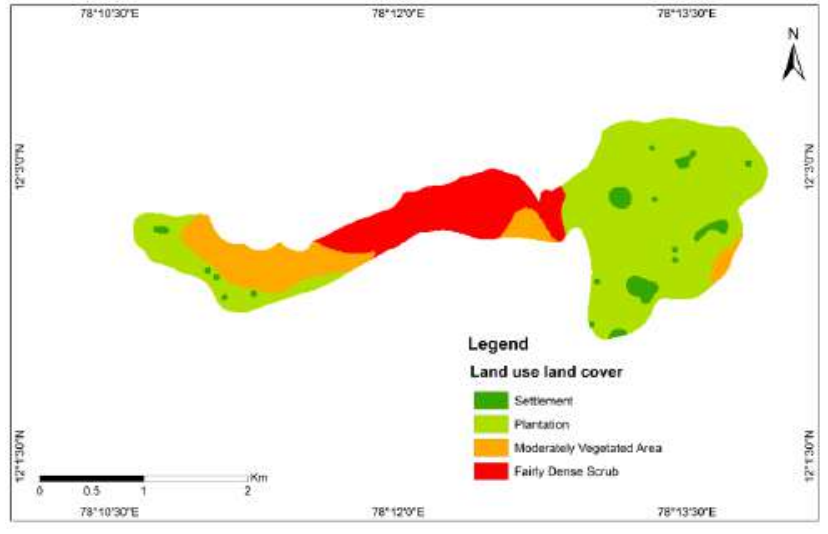

Fig. 5. Land use / land cover in the study area

\section{Slope}

The nature of slope in a terrain controls the stability or failure of slope. Slope inclination is one of the mandatory parameters required for occurrence of landslides. Plains and gentle slopes are always free from landslide occurrences. Slope in degree is the form between any part of the surface of the earth and a horizontal datum (Ayalew et al 2004). SRTM DEM data was utilized to obtain a slope map for the study area. In the present study, the slope map was categorized into five classes ; $0^{\circ}-11^{\circ}, 11^{\circ}-19^{\circ}, 19^{\circ}-27^{\circ}, 27^{\circ}-31^{\circ}$ and $31^{\circ}-38^{\circ}$ respectively (Fig.6).

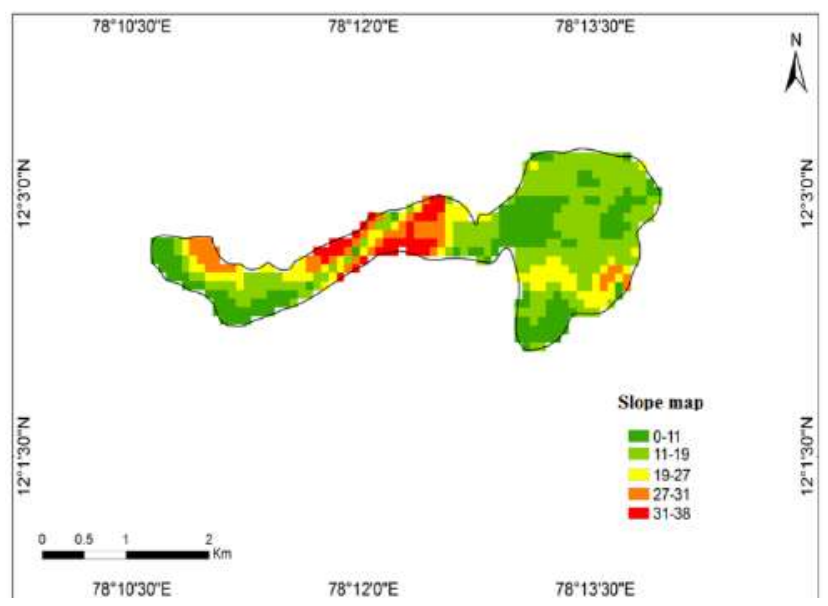

Fig.6. Slope (degree) categories of the study area 


\section{Slope aspect}

Slope aspect is another important parameter, which denotes the direction of maximum slope of a terrain. It is an indirect factor which affects slope instability. In the study area, the aspect map is classified into flat, north, northeast, east, southeast, south, southwest, west and northwest directions. The slope aspect map is useful to understand the impact of sunlight and local microlevel climate of the area. The aspect map was derived from SRTM DEM data (Fig.7).

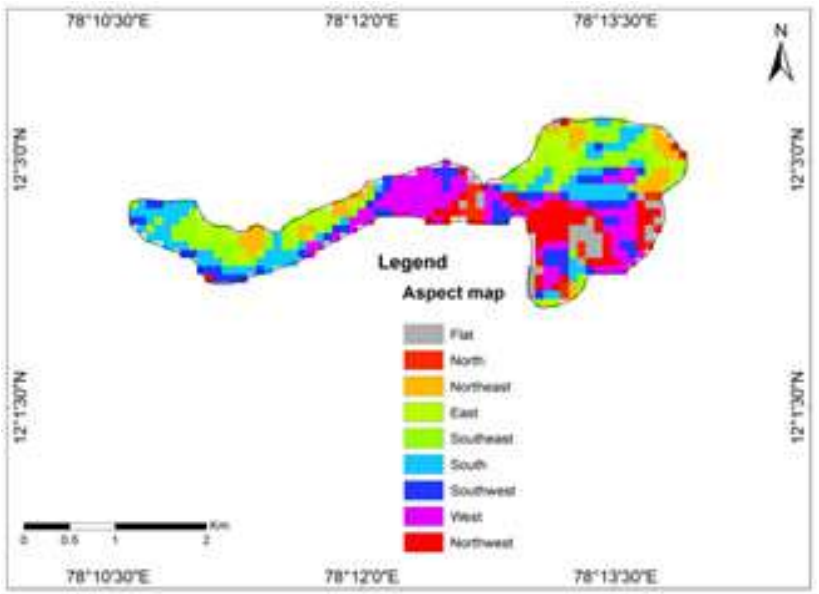

Fig. 7. Slope aspects map of Vathalmmalai Ghat road section

\section{Drainage density}

Besides soil type and geotechnical properties , drainage and drainage density are the causative factors which control occurrence of landslides . Drainage density is the total length of all streams and rivers in a drainage basin divided by the total area of the drainage basin. Sarkar and Karungo (2004) stated that there is an adverse relationship between landslides and drainage density. The drainage density map was generated from drainages extracted from the Survey of India toposheet using ArcGIS tool. Further, the drainage density in the study area is grouped into three classes ; low, medium and high (Fig.8).

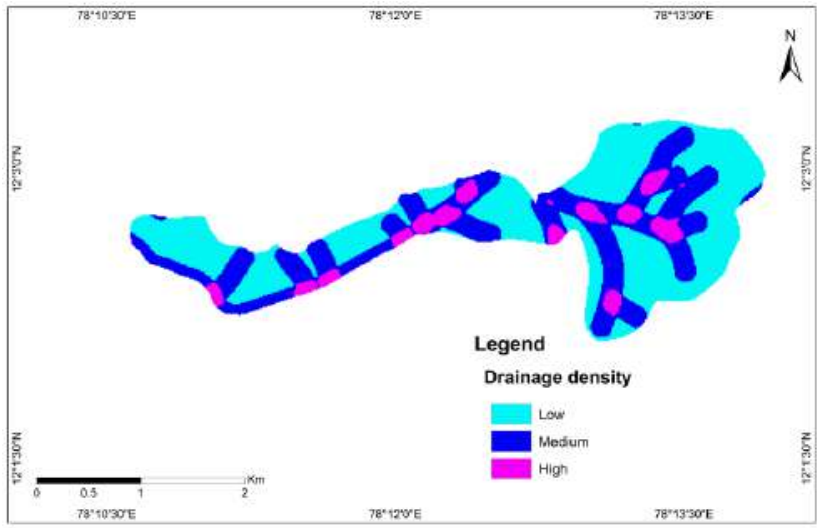

Fig. 8. Drainage density map for the study area

\section{Lineament density}

Lineament in general defined as any straight-line features in the satellite image, controlled by structural features like fault, fold axis, dyke, joints, fractures, etc., Lineament density is considered one of the important parameters in landslide studies. The IRS P6 LISS III Satellite image was used to interpret the lineaments in the study area. The major lineaments were identified in the northern and southern part of this study area and few landslide occurrences were noticed in the north-west and south-east directions. The lineament density map was derived from the lineament map and reclassified into three categories ; low, medium and high (Fig.9).

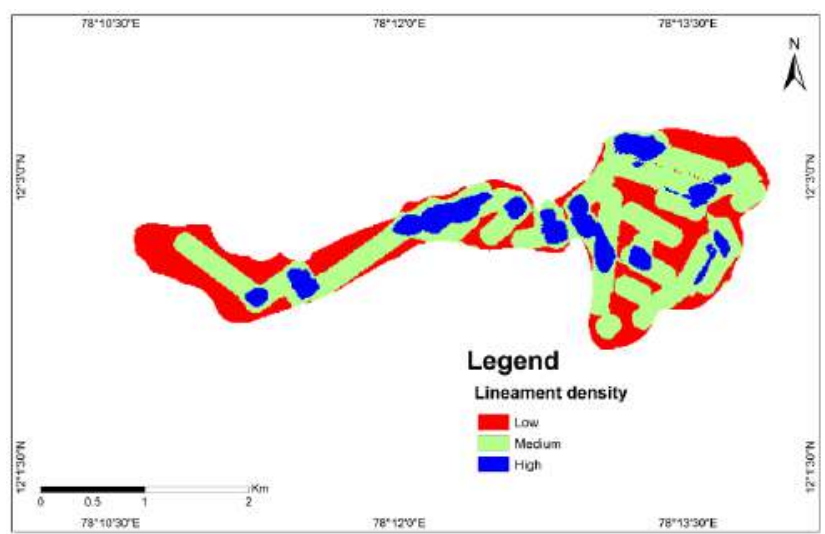

Fig. 9. Lineament density map of Vathalmalai Ghat road section

\section{Road buffer}

Road cutting is one key factor that affects the modification of natural slope into cut slope. Road construction is a significant factor which causes slope instability in a terrain. In this study, a buffer zone with $50 \mathrm{~m}$ distance on both side of the road was generated using Arc GIS software. The road buffer zone was classified into three categories 25m, 50,100m (Fig.10).

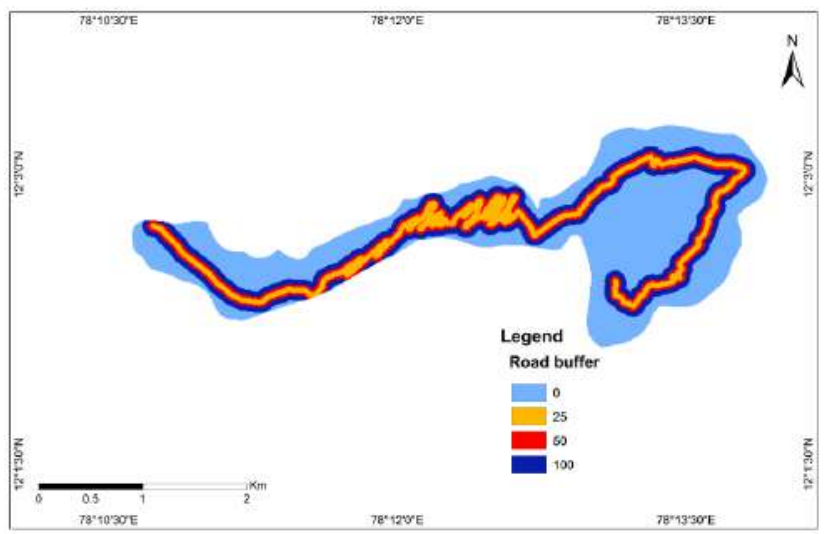

Fig.10. Road buffer zone along the Ghat road section of the Vathalmalai Hills 


\section{Relative relief}

Relative relief denotes the maximum and minimum height in the study area. Relative relief is one of the important terrain parameters which control the occurrence of landslides. In this study area, the relative relief ranges from 500 to $1180 \mathrm{~m}$. It was classified into two classes, low and medium relative relief zones (Fig.11).

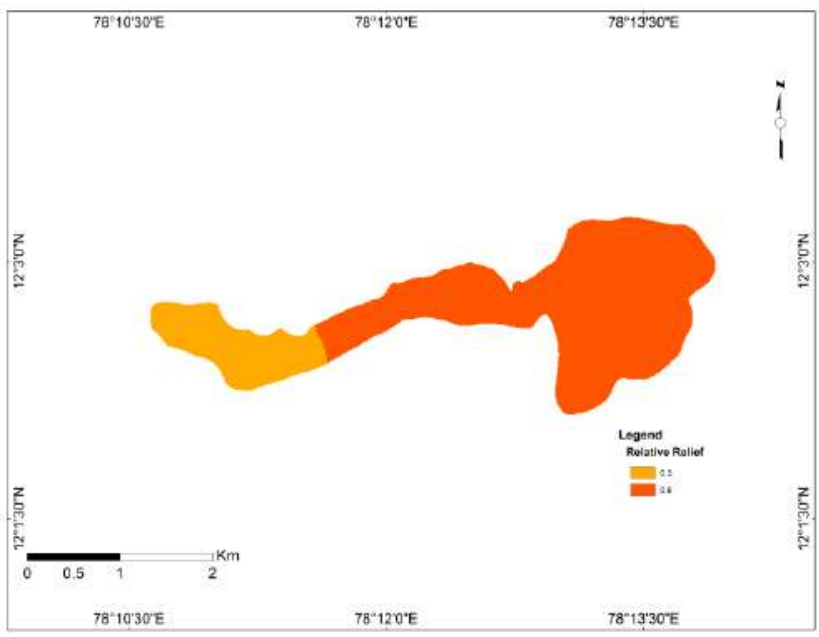

Fig. 11. Relative relief in the study area

\section{Weighted linear combination (WLC)}

Weighted linear combination (WLC) function aggregates all criteria and produce a single score. WLC is a function used to standardize the factor maps, ensuring the sum of the set of factors weights. The weightage and scores were assigned to all causative parameters according to its contribution to susceptibility of landslide occurrence. Landslide susceptibility index formula is given in the equation 1 .

Susceptibility index $=\sum_{i=1}^{n}(W \mathrm{i} \times R \mathrm{i})$

Where $W_{1}$ is the weight for factor $\mathrm{i}$,

$R \mathrm{i}$ is the score of class of factor $\mathrm{i}$ and $n$ is the total number of factors

(Muheep et.al 2018).

The weightage from 0 to 100 and scores from 0 to10 were assigned each causative factor in the study (Table 1). The landslide inventory details were collected through field investigation and validated the distribution of landslide susceptibility classes.

\section{Results and Discussion}

In the present study, weighted linear combination analysis was adopted for the purpose of the calculation of the landslide susceptibility index (LSI). All the causative factors processed and converted the vector based layers into raster format with a $10 \mathrm{~m}$ grid size of
Table 1. Ranking and weights assignment to causative factors

\begin{tabular}{|c|c|c|c|c|}
\hline S. No & Factors & Classes & Weights & Rank \\
\hline \multirow[b]{2}{*}{1} & \multirow[b]{2}{*}{ Geology } & Charnockite & \multirow[b]{2}{*}{15} & 7 \\
\hline & & $\begin{array}{l}\text { Basic alkaline } \\
\text { dykes }\end{array}$ & & 5 \\
\hline \multirow{3}{*}{2} & & $\begin{array}{l}\text { Structural hill } \\
\text { system }\end{array}$ & \multirow{3}{*}{10} & 9 \\
\hline & & Pediment & & 8 \\
\hline & & Fracture valley & & 4 \\
\hline \multirow{4}{*}{3} & \multirow{4}{*}{$\begin{array}{l}\text { Land Use / } \\
\text { Land Cover }\end{array}$} & Settlement & \multirow{4}{*}{15} & 7 \\
\hline & & Plantation & & 6 \\
\hline & & $\begin{array}{l}\text { Moderately } \\
\text { Vegetated area }\end{array}$ & & 6 \\
\hline & & Fairly Dense Scrub & & 9 \\
\hline \multirow{5}{*}{4} & \multirow{5}{*}{ Slope } & $0-11$ & \multirow{5}{*}{10} & 3 \\
\hline & & $11-19$ & & 3 \\
\hline & & $19-27$ & & 7 \\
\hline & & $27-31$ & & 5 \\
\hline & & $31-38$ & & 8 \\
\hline \multirow{9}{*}{5} & \multirow{9}{*}{ Slope Aspect } & Flat & \multirow{9}{*}{20} & 0 \\
\hline & & North & & 1 \\
\hline & & Northeast & & 2 \\
\hline & & East & & 3 \\
\hline & & Southeast & & 4 \\
\hline & & South & & 5 \\
\hline & & Southwest & & 7 \\
\hline & & West & & 8 \\
\hline & & Northwest & & 9 \\
\hline \multirow{3}{*}{6} & \multirow{3}{*}{$\begin{array}{l}\text { Drainage } \\
\text { Density }\end{array}$} & Low & \multirow{3}{*}{10} & 9 \\
\hline & & Medium & & 8 \\
\hline & & High & & 5 \\
\hline \multirow{3}{*}{7} & \multirow{3}{*}{$\begin{array}{l}\text { Lineament } \\
\text { Density }\end{array}$} & Low & \multirow{3}{*}{5} & 9 \\
\hline & & Medium & & 7 \\
\hline & & High & & 6 \\
\hline \multirow{4}{*}{8} & \multirow{4}{*}{ Road Buffer } & 0 & \multirow{4}{*}{10} & 9 \\
\hline & & 25 & & 8 \\
\hline & & 50 & & 6 \\
\hline & & 100 & & 4 \\
\hline \multirow[t]{2}{*}{9} & $\begin{array}{l}\text { Relative } \\
\text { Relief }\end{array}$ & 0.3 & 5 & 7 \\
\hline & & 0.6 & & 9 \\
\hline
\end{tabular}

IRS P6 LISS III satellite imagery with help of spatial analysis tool for ArcGIS 10.4.1 software. The landslide influencing factors were integrated and converted into raster format through calculation of values and scores. The integrated landslide susceptibility zonation map of the study area contains five cluster zones ; very low, low, moderate, high and very high . The percentage 
distribution of susceptibility zones is $16.5 \%$ in very low, $28.70 \%$ in low, $24.70 \%$ in moderate, $19.90 \%$ in high and $10.20 \%$ in very high zones (Fig. 12). Out of the five classes, the high and very high landslide susceptibility zone occupied a limited part of the area. The integrated resultant landslide susceptibility map shows that the middle part of the Ghat road section is more prone to occurrence of future landslides.

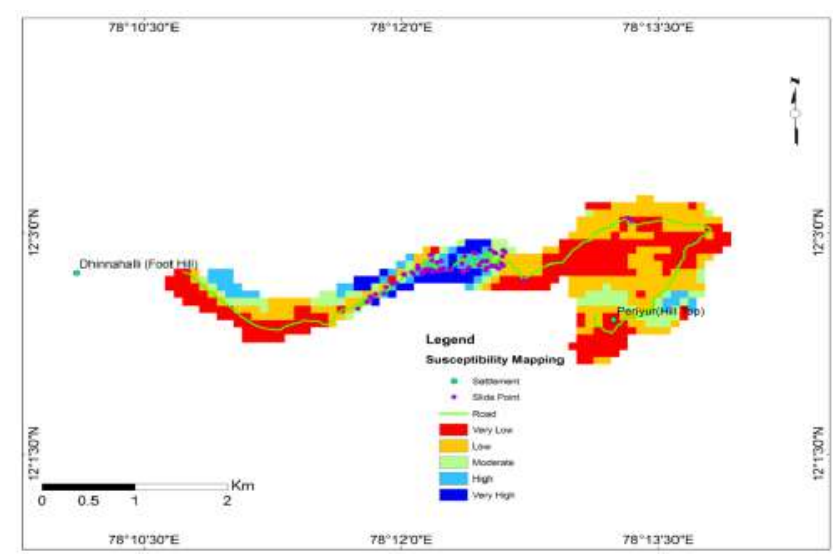

Fig.12. Landslide Susceptibility Map of Vathalmalai Ghat road section

The landslide inventory details were collected during field investigation and used in validation of landslide susceptibility mapping analysis. In the susceptibility zone, several types of landslide activities were identified as debris flow mixed with mud and water in flowing condition, rockfall on the steep slopes, weathered charnockite rock formation and piping phenomena in the soil profile. Landslide occurrences were noticed along 3, 6, 7, 11, 12, 15, 16, 17 and 21 hairpin bends. The landslide locations were captured through GPS measurements during field investigations. Most of the landslides consist of debris, where water acts as lubricant with highly weathered soil. In almost all the landslide locations, the parent rock is not visible and the entre slope section is in weathered conditions. Altogether 62 landslide locations were delineated in different sizes during the landslide inventory. The landslide inventory locations were compared with the landslide susceptibility map and validate the accuracy of the mapping. There are five susceptibility zones in the map ; very low, low, moderate, high and very high. In the correlation, 22 landslides fall within very high zones, 17 within high zones, 13 within moderate zones, 7 within low zones and 3 within very low zones. In comparison, $35.50 \%$, and $27.40 \%$ of landslide occurrences respectively fall within very high and high landslide susceptibility zones. About $64 \%$ of previous landslides were closely associated with high to very high category and the multicriteria and WLC method were found to be suitable for landslide susceptibility mapping.

The potential map was verified using distribution of landslide locations. For the verification, the R-index method was used. The R-index method is used to evaluate the association between location of landslide points and the LSI map. The aim of validation is to evaluate performance of the landslide density of the study area. An index of relative landslide density (R) has been used to validate the results. The index is defined as follows (Baeza and Corominas, 2001);

$\mathrm{R}=\left(\mathrm{n}_{\mathrm{i}} / \mathrm{N}_{\mathrm{i}}\right) / \sum\left(\mathrm{n}_{\mathrm{i}} / \mathrm{N}_{\mathrm{i}}\right) \times 100$

Where, $n_{i}$ is the number of landslides in susceptibility level ' $\mathrm{i}$ ' and

$\mathrm{N}_{\mathrm{i}}$ is the area occupied by the cells of susceptibility level ' $\mathrm{i}$ '.

The R-index for each landslide class is represented in Table 2, and the graphical representation (Fig.13) points out the distribution of landslide locations observed in the classes, indicating the consistency of landslide density classes. It may be expected that slope failures will appear in cells which have higher discriminant scores.

Table 2. R-index in the landslide susceptibility in the study area

\begin{tabular}{|l|c|c|c|c|c|}
\hline $\begin{array}{c}\text { Susceptibility } \\
\text { Classes }\end{array}$ & $\begin{array}{c}\text { Area } \\
\text { Pixels }\end{array}$ & $\begin{array}{c}\text { Area } \\
\text { \% }\end{array}$ & $\begin{array}{c}\text { Landslide } \\
\text { point }\end{array}$ & $\begin{array}{c}\text { Landslide } \\
\text { \% }\end{array}$ & $\begin{array}{c}\mathbf{R} \\
\text { Index }\end{array}$ \\
\hline Very low & 3894 & $16.50 \%$ & 3 & $4.80 \%$ & 4.59 \\
\hline Low & 6796 & $28.70 \%$ & 7 & $11.30 \%$ & 6.13 \\
\hline Moderate & 5839 & $24.70 \%$ & 13 & $21.00 \%$ & 13.27 \\
\hline High & 4694 & $19.90 \%$ & 17 & $27.40 \%$ & 21.58 \\
\hline Very high & 2410 & $10.20 \%$ & 22 & $35.50 \%$ & 54.41 \\
\hline
\end{tabular}

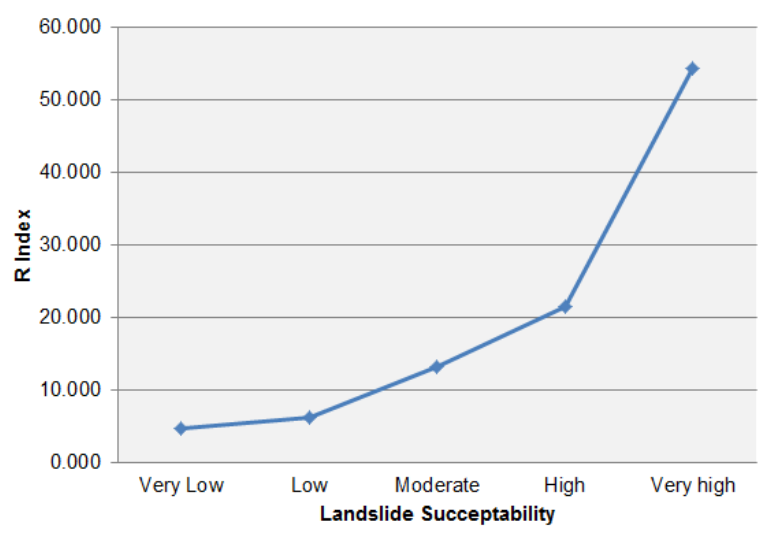

Fig. 13. Graphical representation of R-index of landslide susceptibility

\section{Conclusion}

The Vathalmalai Ghat road section is susceptible to frequent landslide occurrences and the most common triggering factor for landslide occurrence is heavy rainfall. In the present study, landslide susceptibility mapping has been carried out using multi criteria analysis with help of remote sensing and Geographical Information System (GIS) techniques. In this study, nine causative factors, namely geology, geomorphology, slope aspect, land use land cover, drainage density, 
lineament density, road buffer, slope angle, and relative relief were considered for generation of a landslide susceptibility map. The results indicated that the high and very high susceptible zones include steep slope and unconsolidated materials in cut slope areas. The $\mathrm{R}$-index method was used to validate the results of landslide susceptible mapping and it indicated that the procedure adopted in this study is appropriate and valid. Careful planning and suitable mitigation measures are required in moderate, high and very high landslide susceptibility zones. In the landslide inventory study, it was inferred that soil erosion, piping and saturation of highly weathered soil profile lead to slope failure. Hence, a proper drainage mechanism should be provided

\section{References}

Anbalagan, R., 1992. Landslide Hazard Evaluation and Zonation Mapping in Mountainous Terrain, Engineering Geology, 32:269-277

Anbazhagan, S., Neelakantan, R., Arivazhagan, S., Vanaraju, G., 2008. Developments of fractures and land subsidence at Kolli Hills, Tamil Nadu, India. Journal of Geological Society of India, Vol.42, September, 348-352

Anbazhagan, S., Ramesh, V., 2014. Landslide hazard zonation mapping in ghat road section of Kolli hills, India. J Mt Sci 11(5):1308-1325

Anbazhagan, S., Ramesh, V., Saranaathan, S. E., 2017. Cut slope stability assessment along ghat road section of Kolli hills, India. Natural Hazards. DOI 10.1007/ s11069-016-2731-0

Amit, Bera, Bhabani Prasad Mukhopadhyay and Debasish, Das, 2019. Landslide hazard zonation mapping using multi criteria analysis with the help of GIS techniques: a case study from Eastern Himalayas, Namchi, South Sikkim. Natural Hazards, pp: 935-959, doi.org/10.1007/ s11069-019-03580

Ayalew, L., Yamagishi, H., Ugawa, N., 2004. Landslide susceptibility mapping using GISbased weighted linear combination, the case in Tsugawa area of Agano River, Niigata Prefecture, Japan. Landslides 1(1):73-81

Arnous, M., 2011. Integrated remote sensing and GIS techniques for landslide hazard zonation: a case study Wadi Watier area, South Sinai, Egypt. J Coast Conserv 15(4):477-497

Ahmed, B., 2015. Landslide susceptibility mapping using multi-criteria evaluation techniques in Chittagong Metropolitan Area, Bangladesh. Landslides 12(6):10771095. https://doi.org/10.1007/ s1034 6-014-0521-x

Aleotti, P. and Chowdhury, R., 1999. Landslide hazard assessment: summary review and new perspectives. Bulletin of Engineering Geology and the Environment 58. 21-44. DOI: 10.1007/s100640050066

Begueria, S., 2006. Changes in land cover and shallow landslide activity: a case study in the Spanish Pyrenees. Geomorphology 74(1-4):196-206

Baeza, C. and Corominas, J.: 2001. Assessment of shallow landslide susceptibility by means of multivariate for the entire Ghat road section so that soil erosion and soaking of slope can be avoided. Suitable lowprofile plants can be planted to prevent soil erosion. The landslide susceptibility map will assist planners and decision makers in taking appropriate measures to reduce risk in the future.

\section{Acknowledgment}

The first author acknowledges the Department of Science and Technology, New Delhi for providing the INSPIRE Fellowship (2015/IF150252) for the research work. The authors thank the District collectorate, Dharmapuri and District Forest Department for respectively providing necessary data and information.

statistical techniques, Earth Surface Processes and Landforms 26: 1251-1263.

Dai, F.C., Lee, C.F. and Ngai, Y.Y., 2002. Landslide risk assessment and management: an overview. Engineering. Geology 64 (1), 65-87

Jaupaj, O., Lateltin, O., Lamaj, M., 2014. Landslide Susceptibility of Kavaja, Albania. In Landslide Science for a Safer Geoenvironment. 351-356

Hong, Y., Adler, R., Huffman, G., 2007. Use of satellite remote sensing data in the mapping of global landslide susceptibility. Nat Hazards 43:245-256. https://doi. org/10.1007/s1106 9-006-9104-z

Kannan, M., Saranathan, E., Anbalagan, R., 2011. Macro Landslide Hazard Zonation Mapping - Case study from Bodi - Bodimettu Ghat section, Theni District, Tamil $\mathrm{Nadu}$ - India. Journal of Indian Society of Remote Sensing, 39(4):485-496.

Kavitha, G., Anbazhagan, S., Mani, S., 2020a. Spatial Integration of Landslide Hazard Evaluation Factors and Assessment of Landslide prone areas in Vathalmalai hills, India. Disaster Advances Vol 13(7) July 2020, pp 58-68 (E-ISSN: 2278-4543 Print ISSN: 0974-262X,

Kavitha, G., Anbazhagan, S., Mani, S., 2020b. Landslide Inventory along newly Constructed Ghat road section at Vathalmalai Hills, Tamil Nadu, India. Journal of Science and Technology Vol. 5, Issue 2, March-April 2020, 90-98, ISSN: 2456-5660

Lee, S, Choi, J., Min, K., 2004. Probabilistic landslide hazard mapping using GIS and remote sensing data at Boun, Korea. Int J Remote Sens 25(11):2037-2052. https://doi. org/10.1080/01431160310001618734

Meng, Y., Malczewski, J, Boroushaki, S., 2011. A GIS-Based multicriteria decision analysis approach for mapping accessibility patterns of housing development sites: a case study in Canmore, Alberta. J Geogr Inform Syst $3: 50-61$

Muheeb, M. Awawdeh, Mohammad, A. El Mughrabi, and Mohammad, Y. Atallah., 2018. Landslide susceptibility mapping using GIS and weighted overlay method: a case study from North Jordan, Environmental Earth Sciences $77: 732 ; 1-15$ 
Mahdadi, F., Boumezbeur, A., Hadji, R., Kanungo, DP, Zahri, F., 2018. GIS-based landslide susceptibility assessment using statistical models: a case study from Souk Ahras province, NE Algeria. Arab J Geosci 11:476. https://doi. org/10.1007/s1251 7-018-3770-5

Ramesh, V. and Anbazhagan, S., 2014. Landslide susceptibility mapping along Kolli hills Ghat road section (India) using frequency ratio, relative effect and fuzzy logic models, Environmental Earth Science, 73, June 2015, 8009-8021 (Impact Factor - 1.572)

Ramesh, V., Mani, S., Baskar, M., Kavitha. G., Anbazhagan, S., 2017. Landslide hazard zonation mapping and cut slope stability analyses along Yercaud ghat road (Kuppanur-Yercaud) section, Tamil Nadu, India. International Journal of Geo-Engineering 8:2. DOI 10.1186/s40703-017-0039-x

Sajinkumar, K.S., Anbazhagan S., 2014. Geomorphic appraisal of landslides on the windward slope of Western Ghats, southern India, Natural Hazards, Springer, Vol.75, Issue 1 (2015), 953-973 (Impact Factor - 1.958)

Sajinkumar, K.S., Anbazhagan, S., Rani, V.R. \& Muraleedharan, C., 2013. A paradigm quantitative approach for a regional risk Assessment and management in a few landslide prone hamlets along the windward slope of Western Ghats, India, ElsevierInternational Journal of Disaster Risk Reduction, (http://dx.doi.org/10.1016/j.ijdrr, 2013.10.004)
Saranaathan and Mani, 2016. Landslide Susceptibility Zonation mapping using Multi-criterion Analysis-CNG 37 Ghat section, Nadugani, Gudalur Taluk, The NilgirisUsing Geological Factors, International Journal of Earth Science and Engineering. 09(04).

Sarkar, S., Kanungo, D., 2004. An integrated approach for landslide susceptibility mapping using remote sensing and GIS. Photogramm Eng Remote Sens 70(5):617-625

Sharma, R.K., Mehta, B.S., 2012. Macro-zonation of landslide susceptibility in Garamaura-SwarghatGambhar section of national highway 21, Bilaspur District, Himachal Pradesh (India). Natural Hazards, 60:671-688. DOI:10.1007/s11069-011-0041-0.

Varnes, D., 1978. Slope movements, type and processes. In: Schuster RL, Krizek R J (eds) Landslide analysis and control. Washington Transportation Research Board, Special Report 176. NAS, Washington

Wang, W.D,, Xie, C.M,, Du, X.G., 2009. Landslides susceptibility mapping based on geographical information system, GuiZhou, south-west China. Environ Geol 58(1):33-43

Wang, Q., Li, W., Chen, W., Bai, H., 2015. GIS-based assessment of landslide susceptibility using certainty factor and index of entropy models for the Qianyang County of Baoji city, China. J Earth SystSci 124(7):1399-1415 